FINANCIAL: Jurnal Akuntansi

Published by Program Studi Akuntansi STIE Sultan Agung Volume 7-Nomor 2, Desember 2021, (HIm 122-132)

ISSN-P: 2502-4574, ISSN-E: 2686-2581

Available online at: https://financial.ac.id/index.php/financiaI

\title{
PENGARUH MODAL INTELEKTUAL TERHADAP KINERJA PERUSAHAAN PADA INDUSTRI DASAR DAN KIMIA
}

\author{
M. Sienly Veronica ${ }^{1)}$, Ida Ida ${ }^{2)^{*}}$, Syano Joseph ${ }^{3)}$ \\ 1, 2, 3 Program Studi Manajemen, Universitas Kristen Maranatha, J1. Surya Sumantri No.65, Sukawarna, \\ Kec. Sukajadi, Kota Bandung, Jawa Barat 40164, Indonesia \\ E-mail: ${ }^{1}$ lee_pingping@yahoo.com, ${ }^{2}$ ida@eco.maranatha.edu, ${ }^{3}$ syanojoseph@gmail.com \\ *Penulis Korespondensi
}

\begin{abstract}
Abstrak
Riset ini bermaksud menganalisis pengaruh modal intelektual berdasarkan VACA, VAHU, dan STVA terhadap kinerja keuangan perusahaan. Gaya penentuan sampel yang dipergunakan yakni non probabilistic sampling dengan jenis purposive sampling sehingga terdapat 46 perusahaan yang ada pada kelompok industri dasar dan kimia yang terdaftar di BEI yang akan digunakan sebagai sampel sedangkan analisis data yang digunakan untuk menjawab hipotesis penelitian adalah korelasi Pearson. Hasil penelitian menunjukkan bahwa modal intelektual yang terdiri dari VACA, VAHU dan STVA tidak memiliki korelasi terhadap kinerja keuangan perusahaan yang diukur dengan menggunakan rasio return on assets (ROA). Tidak adanya korelasi antara modal intelektual dan kinerja keuangan perusahaan dikarena perusahaan belum maksimal dalam memberdayakan dan mengelola asetaset perusahaan baik yang bersifat tangible assets maupun intangible assets sehingga diharapkan perusahaan dapat lebih memberdayakan aset yang dipunyai oleh perusahaan dengan memberikan pelatihan-pelatihan yang bervariasi kepada karyawan sesuai dengan kompentensi karyawan, mengadopsi teknologi terbarukan agar perusahaan dapat terus kreatif dalam memproduksi produk yang sesuai dengan keinginan dan kebutuhan konsumen dan perusahaan terus mengkomunikasikan nilai-nilai perusahaan kepada semua orang yang terlibat dalam perusahaan untuk dapat meningkatkan kinerja keuangan perusahaan sehingga kinerja perusahaan dapat ditingkatkan pada akhirnya.
\end{abstract}

Kata Kunci: Modal Intelektual, Kinerja Perusahaan, VACA, VAHU, STVA

\section{THE EFFECT OF INTELLECTUAL CAPITAL ON COMPANY PERFORMANCE IN BASIC AND CHEMICAL INDUSTRIES}

\begin{abstract}
This research intends to analyze the effect of intellectual capital based on VACA, VAHU, and STVA on the company's financial performance. The sampling style used was non-probabilistic sampling with purposive sampling type so that there were 46 companies in the basic and chemical industry groups listed on the IDX that would be used as samples while the data analysis used to answer the research hypothesis was the Pearson correlation. The results indicate that intellectual capital consisting of VACA, VAHU and STVA has no correlation with the company's financial performance as measured by using the return on assets (ROA) ratio. There is no correlation between intellectual capital and the company's financial performance because the company has not been maximized in empowering and managing company assets, both tangible and intangible assets, so that it is hoped that the company can further empower the assets owned by the company with providing various trainings to employees according to employee competencies, adopting renewable technology so that companies can continue to be creative in producing products that are in accordance with the wishes and needs of consumers and the company continue to communicate corporate values to everyone involved in the company so that it can improve the company's financial performance so that the company's performance can be improved in the end.
\end{abstract}

Keywords: Intellectual Capital, Company Performace, VACA, VAHU, STVA

Article History: Received: 12 Jul 2021 Revised: 10 Okt 2021 Accepted: 25 Okt 2021 


\section{PENDAHULUAN}

Pada tahun 2018, sektor industri dasar dan kimia tercatat naik paling tinggi yaitu $24.01 \%$ dan tahun 2019 juga mencapai kenaikan terbesar yaitu tumbuh $8.72 \%$ walaupun tidak sebesar di tahun 2018. Kinerja yang baik ini juga tidak lepas dari peningkatan kinerja sektor infrastruktur dan properti. Sektor industri dasar kimia memiliki prospek yang baik karena sektor ini berkaitan dengan sektor lain (Wahyu, 2019). Kinerja yang baik dari sektor industri dasar dan kimia juga tidak terlepas pada pengelolaan perusahaan yang baik.

Dengan perkembangan teknologi, maka terdapat perubahan pengelolaan perusahaan serta strategi perusahaan dalam usaha mencapai perusahaan yang berkinerja lebih produktif. Pengelolaan perusahaan seketika juga mulai difokuskan tak sematamata pada tangible assets, akan tetapi juga mulai pada intangible assets yaitu aset pengetahuan (knowledge asset). Pengetahuan telah diyakini sebagai modal intelektual yang sangat penting bagi kinerja perusahaan dan peningkatan nilai perusahaan. Nilai pasar perusahaan akan meningkat jika perusahaan dapat memanfaatkan modal intelektualnya dengan efisien (Handayani, 2015).

Peningkatan fokus perusahaan pada modal intelektual menghasilkan tantangan dalam pengukuran modal intelektual. Pegukuran asset tidak berwujud sebagai modal intelektual dikemukakan oleh (Pulic, 1998) dengan memperkenalkan koefisien nilai tambah modal intelektual (VAIC ${ }^{\mathrm{TM}}$ ) dengan 3 bagian yakni modal physical, modal manusia, dan modal struktural dengan pengukuran VACA (nilai tambah capital employed), VAHU (nilai tambah human capital), dan STVA (nilai tambah untuk structural capital).
Hal lain yang menjadi dasar dilakukannya riset ini adalah adanya ketidakkonsistenan hasil riset dari beberapa peneliti terdahulu yang juga meneliti modal intelektual dengan kinerja perusahaan. Menurut (Tarigan et al., 2019) dalam penelitiannya yang berkaitan dengan modal intelektual dengan ROA menyatakan bahwa HCE dan SCE tidak berpengaruh terhadap ROA dan hanya CEE yang berpengaruh pada ROA sedangkan (Forte et al., 2019) menyatakan CEE tidak berpengaruh terhadap ROA dan yang berpengaruh terhadap ROA adalah HCE dan SCE. Menurut (Tsai \& Mutuc, 2020) bahwa variabel capital employed (CEE) berpengaruh positif terhadap ROA dan Tobin's Q, variabel human capital (HCE) berpengaruh negatif terhadap ROA dan Tobin's Q sedangkan variabel structural capital (SCE) tidak berpengaruh terhadap ROA. Menurut (Weqar \& Haque, 2020) dan (Hoang et al, 2020) variabel CEE, HCE dan SCE berpengaruh terhadap ROA.

Dikarenakan perkembangan teknologi yang cepat dimana perusahaan harus selalu menyesuaikan dengan perubahan yang terjadi agar dapat bertahan dan meningkatkan kinerjanya serta adanya ketidakkonsistenan hasil riset modal intelektual terhadap kinerja perusahaan maka peneliti tertarik untuk melakukan riset untuk melihat bagaimana sebenarnya impak variabel modal intelektual terhadap kinerja keuangan perusahaan pada perusahaan-perusahaan yang bergerak pada industri dasar dan kimia yang listing di Bursa Efek Indonesia?

Tujuan daripada diadakan riset ini teruntuk menganalisis impak modal intelektual yang diukur atas VACA, VAHU, beserta STVA terhadap kinerja keuangan perusahaan bidang industri dasar dan kimia yang memiliki kinerja yang baik beberapa 
tahun terakhir ini. Kinerja keuangan pada studi ini dinilai dengan salah satu rasio untuk menilai profabilitas yaitu Return on Asset (ROA) karena mencerminkan pengembalian perusahaan dari seluruh aset perusahaan dan modal intelektual menggambarkan elemen dari aset perusahaan.

\section{LANDASAN TEORI}

\section{Intellectual Capital}

Menurut Wijaya \& Amanah (2017), modal intelektual merupakan salah satu sumber daya yang dipunyai oleh perusahaan yaitu selisih antara market value dengan book value pada perusahaan tersebut dimana intellectual capital (modal intelektual) acapkali menjadi komponen penentu utama perolehan keuntungan perusahaan. Modal intelektual melambangkan aset yang sangat bermutu dimana juga diperlukan oleh kelompok eksternal, namun pengakuannya tidak terdapat dalam laporan keuangan (Kartika \& Hatane, 2013). Untuk dapat mengukur nilai dari intellectual capital maka diperlukan suatu metode atau cara tertentu. Metode yang dipergunakan untuk mengukur modal intelektual diciptakan oleh Pulic tahun 1998 dimana intellectual capital (modal intelektual) adalah menilai ketepatgunaan dari nilai tambah (value added) yang dapat diciptakan oleh kompetensi intelektual yang dimiliki perusahaan (Pulic, 1998).

\section{Value Added Intellectual Capital}

$\left(\mathrm{VAIC}^{\mathrm{TM}}\right)$ merupakan cara untuk mempertunjukkan dan mengestimasi informasi berkaitan value creation dari tangible assets beserta intangible assets (Gozali \& Hatane, 2014). $\quad$ VAIC $^{\mathrm{TM}}$ menggunakan 3 ukuran untuk mengukur intellectual capital antara lain:
VACA: parameter nilai tambah yang dibentuk oleh satu satuan atas physical capital. Nilai yang akan diperoleh mengindikasikan sumbangsih yang dibentuk oleh setiap satu satuan dari capital employed terhadap nilai tambah organisasi (Wijayani, 2017). Formulasi yang digunakan untuk mengukur VACA:

\section{$\mathrm{VACA}=\mathrm{VA} / \mathrm{CE}$}

\section{Keterangan:}

VACA $=$ nilai tambah untuk capital employed

$\mathrm{VA}=$ nilai tambah (Depreciation expense + Dividend + Interest expense + Minority interest + Retained profit + Tax expense + Wages and salaries (Wong et al. 2015))

$\mathrm{CE}=$ capital employed/dana yang dimiliki (Total assets - Intangible assets atau Fixed assets + Working capital) (Girma, 2017)

VAHU: memberikan informasi mengenai kapasitas karyawan untuk menciptakan nilai teruntuk perusahaan melalui kapital yang diluncurkan oleh karyawan tersebut. Semakin meningkatnya nilai tambahyang didapatkan dari satu satuan Rupiah yang dipergunakan oleh perusahaan mengisyaratkan bahwa perusahaan sudah memberdayakan sumber daya insani dengan maksimum yang akan menciptakan karyawan berkualitas yang dapat menaikkan kinerja perusahaan pada akhirnya (Harianja, 2014). Formulasi yang digunakan untuk memperoleh nilai VAHU:

$$
\mathrm{VAHU}=\mathrm{VA} / \mathrm{HC}
$$

\section{Keterangan:}

VAHU = nilai tambah human capital

$\mathrm{VA}=$ nilai tambah (Depreciation expense + Dividend + Interest expense + Minority 
interest + Retained profit + Tax expense + Wages and salaries (Wong et al, 2015).

$\mathrm{HC}=$ human capital (biaya karyawan yaitu total honorarium, total gaji karyawan, bonus karyawan, beasiswa untuk karyawan dan lainlain) (Basuki \& Sianipar, 2012).

STVA: merupakan keterlibatan modal struktural dipembentukan value. STVA menghitung total modal struktural yang diperlukan untuk menciptakan satu satuan Rupiah daripada nilai tambah yang menjadikan indikator kemampuan modal struktural dalam pembentukkan value (Wijaya \& Amanah, 2017). Formulasi yang digunakan untuk mencari nilai STVA adalah:

$$
\text { STVA }=\text { SC/VA }
$$

Keterangan:

STVA = nilai tambah untuk structural capital $\mathrm{VA}=$ nilai tambah $=$ Depreciation expense + Dividend + Interest expense + Minority interest + Retained profit + Tax expense + Wages and salaries (Wong et al, 2015). $\mathrm{SC}=$ structural capital: VA - HC(Ulum, 2017).

\section{Kinerja Keuangan}

Kinerja keuangan menggambarkan suatu perkiraan yang dihasilkan dari alat analisis keuangan yang menunjukkan kondisi keuangan perusahaan apakah baik atau buruk. Terdapat berbagai cara mengevaluasi kinerja keuangan perusahaan salah satunya menerapkan kajian rasio keuangan. Rasio keuangan membantu mengetahui kondisi keuangan tertentu lebih jauh (Prihadi, 2008). Rasio keuangan yang dipergunakan untuk menilai kinerja keuangan perusahaan adalah return on assets (ROA), return on assets (ROA) menghitung keuntungan yang diperoleh terhadap aset yang dipergunakan selama memperoleh keuntungan tersebut Copyright (C) 2021, FINANCIAL: Jurnal Akuntansi
(Prihadi, 2008). ROA mencerminkan kedayagunaan perusahaan dalam menggunakan total asetnya (Chen, Cheng, \& Hwang, 2005)

\section{Pengembangan Hipotesis}

VACA didapat dari perbandingan antara nilai tambah terhadap jumlah equity perusahaan. VACA menjelaskan besarnya kontribusi yang dibentuk oleh setiap unit dari equity terhadap nilai tambah sebuah perusahaan dimana perusahaan semakin berusaha dengan baik mengelola VACA, maka pengelolaan ekuitas perusahaan semakin baik (Dewi \& Meirina, 2019). Hal ini sependapat dengan hasil temuan dari peneliti (Mehralian et al, 2012 ), (Lutfillah \& Sukmana, 2018), (Yilmaz \& Acar, 2018) dan (Li et al, 2021) yang menunjukkan adanya pengaruh yang signifikan antara VACA dan ROA, dari penjelasan ini, hipotesis pertama dari riset ini:

$\mathbf{H}_{1}$ : VACA berpengaruh signifikan terhadap kinerja keuangan (ROA) perusahaan

VAHU mengukur seberapa besar nilai tambah yang diperoleh dengan adanya pengeluaran dana yang diperuntukkan untuk tenaga kerja.(Nurhayati, 2017) menyatakan bahwa manusia sebagai bagian modal intelektual maka dengan pengelolaan human capital yang baik dan efektif akan meningkatkan produktivitas sumber daya manusia sehingga akan berpengaruh pada kinerja perusahaan. Hal ini diperkuat oleh hasil penelitian (Thaib, 2013) bahwa VAHU adalah indikator yang paling signifikan untuk menjelaskan konstrukVAICTM dan hasil penelitian (Lusda, Wijayanto, \& Hakim, 2018) yaitu human capital sebagaikomponen modal intelektual yang diukur dengan variabel VAHU memberikan kontribusi yang paling besar pada kinerja perusahaan. Hasil 
penelitian (Thaib, 2013), (Janosevic et al, 2013), (Puspitosari, 2016), (Yilmaz \& Acar, 2018) dan (Weqar dan Haque, 2020) menunjukkan terdapat pengaruh yang signifikan antara VAHU dan ROA, dari penjelasan ini maka hipotesis kedua dari riset ini:

$\mathbf{H}_{2}$ : VAHU berpengaruh signifikan terhadap kinerja keuangan (ROA) perusahaan

STVA mengukur kemampuan perusahaan yang meliputi infrastruktur, rutinitas, sistem informasi, proses dan budaya dalam membantu setiap karyawan menciptakan intellectual yang optimal. Structural capital berwujud sebagai infrastruktur dalam membantu perusahaan dalam menaikkan produktivitas setiap karyawannya dan menciptakan nilai tambah bagi perusahaan (Dewi \& Meirina, 2019). Hal ini sejalan dengan hasil penelitian (Khanqah et al, 2012), (Thaib, 2013), (Puspitosari, 2016), (Lutfillah \& Sukmana, 2018) serta (Hoang et al, 2020) yang menyiratkan bahwa diperoleh pengaruh yang signifikan antara STVA dan ROA, dari penjelasan ini, maka hipotesis ketiga dari riset ini:

$\mathbf{H}_{3}$ : STVA berpengaruh signifikan terhadap kinerja keuangan (ROA) perusahaan

\section{METODE}

Populasi di dalam riset ini yakni perusahaan-perusahaan yang termasuk dalam industri dasar dan kimia di Indonesia. Dalam riset ini sampel yang dipergunakan adalah perusahaan yang berkecimpung pada industri dasar dan kimia yang Listing di Bursa Efek Indonesia. Gaya penentuan sampel yang dipergunakan dalam riset ini adalah non probabilistic sampling dengan tipe purposive sampling. Purposive sampling dilaksanakan dengan menarik sampel dari populasi Copyright (C) 2021, FINANCIAL: Jurnal Akuntansi berlandaskan suatu standar yang spesifik (Hartono, 2012). Standar yang dipergunakan di dalam riset ini yakni perusahaan tercatat di Bursa Efek Indonesia sebelum tahun 2014, berkecimpung di industri dasar dan kimia, dan konsisten mengeluarkan laporan keuangan dari tahun 2014-2019. Berdasarkan standar tersebut maka total sampel yang dipergunakan di riset ini adalah 46 perusahaan yang berkecimpung di industri dasar dan kimia yang listing di Bursa Efek Indonesia. Teknik analisis data menggunakan metode analisis regresi berganda dengan proses pertama melakukan pengujian asumsi klasik, bila pada pengujian asumsi klasik salah satu pengujian asumsi klasik tidak terpenuhi maka teknik analisis data yang digunakan adalah korelasi Pearson.

\section{HASIL DAN PEMBAHASAN}

Proses pertama peneliti melaksanakan uji asumsi klasik. Hasil Asymp-Sig (2-tailed) uji normalitas adalah 0,000 sehingga data tak berdistribusi normal sebab nilai Asymp-Sig (2-tailed) $\leq$ nilai $\alpha$ yaitu 5\%. Peneliti melakukan natural logaritma kepada semua data penelitian dan melakukan uji normalitas kembali dengan data hasil natural logaritma dan diperoleh nilai Asymp-Sig (2-tailed): 0,226 , data berdistribusi normal sebab nilai Asymp-Sig (2-tailed) $>5 \%$.

Setelah uji normalitas maka peneliti melakukan uji heteroskedasitas dimana nilai uji heteroskedasitas dapat diamati di tabel 2.

Tabel 2. Nilai Uji Heteroskedasitas

\begin{tabular}{|c|c|c|c|c|c|}
\hline \multirow{2}{*}{ Model } & \multicolumn{2}{|c|}{$\begin{array}{c}\text { Unstandardized } \\
\text { Coefficients }\end{array}$} & \multirow{2}{*}{$\mathrm{t}$} & \multirow{2}{*}{ Sig. } \\
\cline { 2 - 6 } \multicolumn{2}{c|}{} & $\mathrm{B}$ & Std. Error & & \\
\hline \multirow{4}{*}{1} & (Constant) & .949 & .188 & 5.058 & .000 \\
\cline { 2 - 6 } & LNVACA & -.003 & .060 & -.052 & .958 \\
\cline { 2 - 6 } & LNVAHU & -.024 & .070 & -.348 & .728 \\
\hline & LNSTVA & .177 & .201 & .880 & .380 \\
\hline
\end{tabular}

Sumber: Hasil Olahan SPSS 
Hasil uji heteroskedasitas menggambarkan bahwa data terbebas dari heteroskedasitas karena nilai Sig yang dihasilkan untuk semua variabel penelitian $>$ $5 \%$.

Uji multikolinieritas juga dilakukan dalam riset ini dimana tabel 3 menyampaikan informasi berkaitan dengan nilai uji multikolinieritas. Hasil menunjukkan bahwa data dalam variabel studi ini terbebas dari multikolinieritas.

Tabel 3 Nilai Uji Multikolinieritas

\begin{tabular}{|c|l|r|r|}
\hline \multicolumn{2}{|c|}{ Model } & \multicolumn{2}{c|}{ Collinearity Statistics } \\
\cline { 3 - 4 } \multicolumn{2}{|c|}{} & Tolerance & \multicolumn{1}{c|}{ VIF } \\
\hline \multirow{4}{*}{1} & (Constant) & & \\
\cline { 2 - 4 } & LNVACA & .418 & 2.390 \\
\cline { 2 - 4 } & LNVAHU & .346 & 2.893 \\
\cline { 2 - 4 } & LNSTVA & .715 & 1.398 \\
\hline
\end{tabular}

Sumber: Hasil Olahan SPSS

Uji asumsi klasik yang terakhir ialah uji autokorelasi. Nilai uji autokorelasi untuk riset ini disampaikan pada tabel 4 .

Tabel 4 Nilai Uji Autokorelasi

\begin{tabular}{|l|r|}
\hline & $\begin{array}{c}\text { Unstandardized } \\
\text { Residual }\end{array}$ \\
\hline Test Value & a \\
\hline Cases $<$ Test Value & .17694 \\
\hline Cases $>=$ Test Value & 85 \\
\hline Total Cases & 86 \\
\hline Number of Runs & 171 \\
\hline Z & 47 \\
\hline Asymp. Sig. (2-tailed) & -6.059 \\
\hline
\end{tabular}

Sumber: Hasil Olahan SPSS

Hasil uji autokorelasi menunjukkan bahwa terjadi autokorelasi dalam data penelitian karena nilai Asymp.Sig (2-tailed) yang dihasilkan $\leq 5 \%$. Oleh karena itu peneliti menggunakan metode korelasi Pearson dalam melakukan pengujian hipotesis penelitian.

Copyright (C) 2021, FINANCIAL: Jurnal Akuntansi
Tabel 5 Hasil Korelasi Pearson

\begin{tabular}{|c|l|c|c|c|c|}
\hline \multicolumn{6}{|c|}{ Correlations } \\
\hline \multirow{5}{*}{ LNROA } & $\begin{array}{r}\text { LN } \\
\text { VACA }\end{array}$ & $\begin{array}{c}\text { LN } \\
\text { VAHU }\end{array}$ & $\begin{array}{c}\text { LN } \\
\text { STVA }\end{array}$ & $\begin{array}{c}\text { LN } \\
\text { ROA }\end{array}$ \\
\hline \multirow{5}{*}{$\begin{array}{l}\text { Pearson } \\
\text { Correlation }\end{array}$} & .009 & -.109 & -.038 & 1 \\
\cline { 2 - 7 } & $\begin{array}{l}\text { Sig. (2- } \\
\text { tailed) }\end{array}$ & $\mathbf{. 9 0 5}$ & $\mathbf{. 1 2 7}$ & $\mathbf{. 6 0 3}$ & \\
\cline { 2 - 7 } & $\mathrm{N}$ & 182 & 198 & 186 & 198 \\
\hline
\end{tabular}

Sumber: Hasil Olahan SPSS

Hasil korelasi Pearson menunjukkan bahwa tidak terdapat korelasi antara VACA terhadap ROA karena nilai Sig yang dihasilkan: $0,905>5 \%$ sehingga hipotesis penelitian 1 tidak dapat diterima. Hasil riset ini didukung oleh temuan yang diperoleh oleh peneliti (Firer \& Williams, 2003), (Maditinos et al, 2011), (Janosevic et al, 2013), (Kamath, 2015), (Smriti \& Das, 2017), (Yudawisastra, Manurung, \& Husnatarina, 2018), (Nassar, 2018), dan (Abbasi et al, 2019). Peneliti-peneliti tersebut menyatakan bahwa VACA tidak berkorelasi dengan ROA dan juga tiada pengaruh terhadap ROA. Hasil riset ini menerangkan bahwa perusahaan-perusahaan sampel tiada mengatur penggunaan sumber daya baik tangible asset maupun intangible asset dengan maksimal sehingga nilai ROA perusahaan-perusahaan sampel yang mengalami peningkatan atau penurunan bukan berasal dari pemanfaatan sumber daya perusahaan, selain itu hasil ini juga menggambarkan bahwa perusahaanperusahaan sampel melakukan investasi yang tidak banyak dalam meningkatkan sumber daya perusahaan yang dapat digunakan untuk bersaing dengan pesaing maupun meningkatkan kinerja keuangan perusahaan.

Hipotesis penelitian ke dua juga ditolak karena nilai Sig yang dihasilkan adalah $0,127>5 \%$ sehingga VAHU tidak berkorelasi dengan ROA. Hasil riset ini 
sesuai dengan penemuan yang diperoleh dari penelitian yang dikerjakan oleh peneliti (Firer \& Williams, 2003), (Maditinos et al, 2011), (Joshi et al, 2012), (Khanqah et al, 2012), (Venugopal \& Subha, 2015), (Dzenopoljac et al, 2016), (Smriti \& Das, 2017), (Nassar, 2018) dan (Abbasi et al., 2019). Para peneliti menyatakan bahwa tidak terjadi korelasi antara VAHU dan ROA selain itu menurut (Kartika \& Hatane, 2013) dalam penelitiannya mendapati bahwa VAHU bernilai tidak positif dan tidak punya pengaruh yang signifikan terhadap profitabilitas. Hal tersebut mengindikasikan bahwa perusahaan-perusahaan sampel tidak menggunakan secara maksimal keahlian yang dipunyai oleh karyawan perusahaan sampel tersebut dalam menaikkan kinerja keuangan perusahaan sampel selain itu menurut (Buallay, 2017) tidak berpengaruhnya VAHU terhadap ROA disebabkan karena perusahaan tidak menyadari potensi yang ada dalam karyawan sehingga tidak dapat memaksimalkan ROA perusahaan.

Nilai Sig dari korelasi Pearson untuk variabel STVA adalah 0,603 > 5\% sehingga boleh dinyatakan bahwa hipotesis penelitian ketiga juga ditolak artinya STVA tidak berkorelasi dengan ROA. Hasil riset ini selaras dengan penemuan yang terdapat di peneliti (Firer \& Williams, 2003), ( Maditinos, et al 2011 ), (Mehralian et al,2012), (Dzenopoljac et al, 2016), (Smriti \& Das, 2017), (Chowdhury, et al, 2018), (Abbasi et al., 2019), (Budiarso, 2019), (Tsai \& Mutuc, 2020) dan (Li et al, 2021) dimana para peneliti mengungkapkan bahwa tidak ditemukan adanya korelasi antara STVA dan ROA. Menurut (Nuryaman, 2015) STVA tidak memberikan pengaruh secara signifikan terhadap ROA.

Copyright (C) 2021, FINANCIAL: Jurnal Akuntansi
Hasil studi ini menggambarkan bahwa perusahaan-perusahaan sampel belum memperhatikan pengelolaan struktur capital yang meliputi pengelolaan database, pengelolaan sistem informasi, pengelolaan prosedur sehingga mengakibatkan kinerja kerja karyawan menjadi tidak maksimal sehingga perusahaan memperoleh kinerja keuangan yang tidak maksimal, selain itu menurut (Dermawan, 2015) STVA tidak berpengaruh signifikan terhadap ROA dikarenakan strukturnya yang belum mampu berkontribusi pada upaya karyawan dalam membuahkan kinerja intelektual yang optimum.

\section{SIMPULAN DAN SARAN}

Didasarkan pada hasil pengujian hipotesis penelitian maka peneliti menarik simpulan yaitu semua variabel independen (VACA, VAHU, STVA) dalam penelitian ini tidak berkorelasi dengan variabel dependen (ROA), peneliti menduga bahwa perusahaan sampel belum secara maksimal memanfaatkan sumber daya yang dimiliki, kurang mengikuti perkembangan teknologi dan kurang menggali potensi yang dimiliki karyawan sehingga terpotret pada ROA yang dihasilkan oleh perusahaan sampel meningkat bukan disebabkan oleh intangible asset yang mengalami peningkatan.

Oleh karena itu dalam riset ini peneliti menyarankan kepada perusahaan sampel untuk mulai memperhatikan intangible asset seperti mulai melihat potensi-potensi yang dimiliki karyawan dan mengembangkan potensi karyawan melalui pemberian pelatihan, mengikuti perkembangan teknologi dengan cara berusaha mengadopsi teknologi terbarukan dan mengkomunikasikan nilai-nilai yang dianut perusahaan kepada semua orang yang terlibat dalam perusahaan dan memanfaatkan 
semua sumber daya yang dimiliki secara maksimal agar dapat bersaing di dalam industri tersebut. Riset yang dilakukan masih jauh dari kata ideal sehingga peneliti menyarankan untuk mengembangkan peneliti ini dengan menggunakan variabel kinerja keuangan lain seperti ROE, memperpanjang waktu pengamatan, menambah jumlah perusahaan yang diteliti dan menggunakan perusahaan dari industri lain untuk diteliti.

\section{ACKNOWLEDGMENT}

Peneliti mengutarakan terima kasih kepada Universitas Kristen Maranatha yang telah memberikan dukungan pendanaan pada riset ini sehingga riset ini dapat selesai.

\section{DAFTAR PUSTAKA}

Abbasi, K. R., Lv, K., Arif, M., Fawad, R., \& Jaffar, A. (2019). Impact of Intellectual Capital on Performance of Karachi Stock Exchange 30-Index Companies of Pakistan. European Online Journal of Natural and Social Sciences, 8(1), 151169. Retrieved from http://www.european-science.com

Basuki, B., \& Sianipar, M. (2012). Intellectual Capital and Its Impact on Financial Profitability and Investors' Capital Gain on Shares. Journal of Economics, Business, and Accountancy | Ventura, 15(1), 101. https://doi.org/10.14414/jebav.v15i1.63

Buallay, A. M. (2017). The relationship between intellectual capital and firm performance. Corporate Governance and Organizational Behavior Review, 1(1),32-41. https://doi.org/10.22495/cgobr_v1_i1_p 4

Budiarso, N. S. (2019). Intellectual Capital in Public Sector. Accountability, 8(1), 42.https://doi.org/10.32400/ja.23359.8.1 .2019.42-50

Chen, M. C., Cheng, S. J., \& Hwang, Y. (2005). An empirical investigation of the relationship between intellectual capital and firms' market value and financial performance. Journal of Intellectual Capital, 6(2), 159-176. https://doi.org/10.1108/1469193051059 2771

Chowdhury, L.A.M., Rana, T., \& Azim, M.T. (2019). Intellectual Capital Efficiency And Organisational Performance In The Context Of The Pharmaceutical Industry In Bangladesh. Journal Of Intellectual Capital, 20 (6), 784-806.

Dermawan, E. S. (2015). Kaitan Intellectual Capital Terhadap Rasio Profitabilitas Perusahaan Industri Barang Konsumsi Yang Terdaftar Di Bursa Efek Indonesia Pada Periode 2014-2015. Akuntansi Krida Wacana, 17(1), 15-32.

Dewi, M. K., \& Meirina, E. (2019). Capital Intellectual Yang Mempengaruhi Kinerja Keuangan Dengan Menggunakan ROE Sebagai Indikator Pengukuran (Studi Pada BPD Sumatera Barat). Jurnal Benefita, 4(2), 336. https://doi.org/10.22216/jbe.v4i2.4117

Dzenopoljac, V., Janosevic, S., \& Bontis, N. (2016). Intellectual Capital And Financial Performance In The Serbian ICT Industry. Journal Of Intellectual Capital, 17 (2), 373-396.

Firer, S., \& Williams, S.M. (2003), Intellectual Capital And Traditional Measures Of Corporate Performance. Journal Of Intellectual Capital, 4 (3), 348-360.

Forte, W., Matonti, G., \& Nicolo, G. (2019). The Impact Of Intellectual Capital On Firms' Financial Performance And Market Value: Empirical Evidence From Italian Listed Firms. African Journal Of Business Management, 13 (5), 147-159.

Girma, B. (2017). Intellectual Capital Efficiency and Its Impact on Financial Performances of Ethiopian Commercial Banks. Research Journal of Finance and Accounting, 8(8), 17-31.

Gozali, A., \& Hatane, S. E. (2014). Pengaruh 
Intellectual Capital Terhadap Kinerja Keuangan Dan Nilai Perusahaan Khususnya Di Industri Keuangan Dan Industri Pertambangan Yang Terdaftar Di Bursa Efek Indonesia Tahun 2008 2012. Business Accounting Review, 2(2), 208-217. Retrieved from http://publication.petra.ac.id/index.php/a kuntansi-bisnis/article/view/2401

Handayani, I. (2015). Pengaruh Modal Intelektual Terhadap Nilai Perusahaan Manufaktur. E-Jurnal Katalogis, 3(9), 21-30.

Harianja, H. (2014). Analisis Value Added Sebagai Indikator Intellectual Capital Terhadap Kinerja Perbankan Di Indonesia. Jurnal Ekonomi Dan Keuangan, 2(5), 14793.

Hartono, J. (2012). Metode Penelitian Bisnis: Salah Kaprah dan PengalamanPengalaman. In Akuntansi dan Penelitian (5th ed.). Yogyakarta: BPFE.

Hoang, H.T., Nguyen, H.T.H., 7 Vu, N.H. (2020). Intellectual Capital And Firm Performance In Vietnam 2012-2016. Int. J. Learning And Intellectual Capital, 17 (1), 27-46.

Janosevic, S., Dzenopoljac, V., \& Bontis, N. (2013). Intellectual Capital And Financial Performance In Serbia. Knowledge And Process Management, 20 (1), 1-11.

Joshi, M., Cahill, D., \& Sidhu, J. (2013). Intellectual Capital And Financial Performance: An Evaluation Of The Australian Financial Sector. Journal of Intellectual Capital, 14 (2), 264-285

Kamath, G.B. (2015). Impact Of Intellectual Capital On Financial Performance And Market Valuation Of Firms In India. International Lettres Of Social And Humanistic Sciences, 48, 107-122.

Kartika, M., \& Hatane, S. E. (2013). Pengaruh Intellectual Capital pada Profitabilitas Perusahaan Perbankan yang terdaftar di Bursa Efek Indonesia pada Tahun 2007-2011. Business Accounting Review, 1(2), 14-25.
Khanqah, V.T., Khosroshahi, M.A., \& Ghanavati, E. (2012). An Empirical Investigation of The Impact Of Intellectual Capital On Firms' Market Value And Financial Performance: Evidence From Iranian Companies. International Journal Of Management And Business Research, 2 (1), 1-12.

Li, X., Nosheen, S., Haq, N.U., \& Gao. X. (2021). Value Creation During Fourth Industrial Revolution: Use Of Intellectual Capital By Most Innovative Companies Of The World. Technological Forecasting and Social Change, 163. https://doi.org/10.1016/j.techfore.2020.1 20479

Lusda, I. K. M., Wijayanto, H., \& Hakim, D. B. (2018). Modal Intelektual Pada Perusahaan-Perusahaan Di Sektor Keuangan Yang Terdaftar Di Bursa Efek Indonesia Periode 2010-2014. Jurnal Ekonomi Dan Kebijakan Pembangunan, 6(1), 58-81. https://doi.org/10.29244/jekp.6.1.58-81

Lutfillah, N. Q., \& Sukmana, N. K. (2018). Modal Intelektual Sebagai Determinan Kinerja Perusahaan. Jurnal Akuntansi Kontemporer, Vol. 10(No.2), 56-68.

Maditinos, D., Chatzoudes, D., Tsairidis, C., \& Theriou, G. (2011). The Impact Of Intellectual Capital On Firms' Market Value And Financial Performance. Journal Of Intellectual Capital, 12 (1), 132-151.

Mehralian, G., Rajabzadeh, A., Sadeh, M.R., \& Rasekh, H.R. (2012). Intellectual Capital And Corporate Performance In Iranian Pharmaceutical Industry. Journal of Intellectual Capital, 13 (1), 138-158.

Michael C. S. Wong, Stephen C. Y. Li, \& Anthony C. T. Ku. (2015). Impacts of Intellectual Capital on Profitability: An Analysis on Sector Variations in Hong Kong. Journal of US-China Public Administration, 12(8), 614-626. https://doi.org/10.17265/15486591/2015.08.003 
Nassar, S. (2018). The Impact Of Intellectual Capital On Corporate Performance Of IT Companies: Evidence From Bursa Istanbul. Journal of Accounting And Applied Busniess Reserach, 1 (3), 1-9.

Nurhayati, S. (2017). Analisa Pengaruh Intellectual Capital Terhadap Kinerja Pasar Dan Kinerja Keuangan Pada Perusahaan Lq45 Yang Terdaftar Di Bursa Efek Indonesia Periode Tahun 2010-2013. Jurnal ASET (Akuntansi Riset), 9(1), 133. https://doi.org/10.17509/jaset.v9i1.5260

Nuryaman. (2015). The Influence of Intellectual Capital on The Firm's Value with The Financial Performance as Intervening Variable. Procedia - Social and Behavioral Sciences, 211(November 2015), 292-298. https://doi.org/10.1016/j.sbspro.2015.11 .037

Prihadi, T. (2008). Deteksi Cepat Kondisi Keuangan: 7 Analisis Rasio Keuangan (1st ed.). Jakarta: PPM.

Pulic, A. (1998). Measuring The Performance of Intellectual Potential in Knowledge Economy. The 2ndMcMaster World Congress On Measuring And Managing Intellectual Capital,. Austrian.

Puspitosari, I. (2016). Pengaruh Modal Intelektual terhadap Kinerja Keuangan pada Sektor Perbankan The Impact of Intellectual Capital on Banking Sectors Financial Performance. Lp3M Stiebbank, 7(1), 43-53.

Rahmawati Wahyu. (2019). Indeks Sektor Industri Dasar dan Kimia Tumbuh Naik Paling Kencang, Ini Kata Analis. Kontan.Co.Id. Retrieved from https://investasi.kontan.co.id/news/indek s-sektor-industri-dasar-dan-kimiatumbuh-naik-paling-kencang-ini-kataanalis , 22 Juni 2020

Smriti, N., \& Das, N. (2017). Impact Of Intellectual Capital On Business Performance: Evidence From Indian Pharmaceutical Sector. Polish Journal of Management Studies, 15(1), 232-243. https://doi.org/10.17512/pjms.2017.15.1 .22

Tarigan, J., Listijabudhi, S., Hatane, S.E., \& Widjaja, D.C. (2019). The Impacts Of Intellectual Capital On Financial Performance: An Evidence From Indonesian Manufacturing Industry. Indonesia Journal of Business And Entrepreneurship, 5 (1), 65-76.

Thaib, F. (2013). Value Added Intellectual Capital (VAHU, VACA, STVA) Pengaruhnya Terhadap Kinerja Keuangan Bank Pemerintah Periode 2007 - 2011. Jurnal Riset Ekonomi, Manajemen, Bisnis Dan Akuntansi, 1(3), 151-159. https://doi.org/10.35794/emba.v1i3.195 1

Tsai, C-H., \& Mutuc, E.B. (2020). Evidence In Asian Food Industry: Intellectual Capital, Corporate Financial Performance, And Corporate Social Responsibility. International Journal of Environmental Reserach And Public Health, 17 (663), 1-21.

Ulum, I. (2017). Intellectual Capital: Model Pengukuran, Framework Pengungkapan \& Kinerja Organisasi. Universitas Muhammadiyah Malang.

Venugopal, D., \& Subha, M. V. (2015). Impact of intellectual capital on corporate performance. Managing Intellectual Capital and Innovation for Sustanable and Inclusive Society, 675687. Retrieved from http://www.toknowpress.net/ISBN/978961-6914-13-0/papers/ML15-131.pdf

Weqar. F., \& Haque, S.M.I. (2020). Intellectual Capital And Corporate Financial Performance In India's Central Public Sector Enterprises. Int. J. Learning And Intellectual Capital, 17 (1), 77-97.

Wijaya, M. H., \& Amanah, L. (2017). Pengaruh Intellectual Capital Terhadap Kinerja Perusahaan Otomotif Di Bursa Efek Indonesia. Jurnal Ilmu Dan Riset Akuntansi, 6, 295-311.

Wijayani, D. R. (2017). Pengaruh Intellectual 
Capital Terhadap Kinerja Keuangan Perusahaan Publik Di Indonesia (Studi Empiris Pada Perusahaan Manufaktur Di BEI 2012-2014). Jurnal Riset Akuntansi Dan Bisnis Airlangga, 2(1), 97-116. https://doi.org/10.31093/jraba.v2i1.23

Yilmaz, I., \& Acar, G. (2018). The Effects of Intellectual Capital on Financial Performance and Market Value: Evidence from Turkey. Eurasian Journal of Business and Economics, 11(21), 117-133. https://doi.org/10.17015/ejbe.2018.021. 07

Yudawisastra, H. G., Manurung, D. T. H., \& Husnatarina, F. (2018). Relationship between value added capital employed, value added human capital, structural capital value added and financial performance. Investment Management and Financial Innovations, 15(2), 222231.

https://doi.org/10.21511/imfi.15(2).2018 .20 